\title{
JUURNAL_RU
}

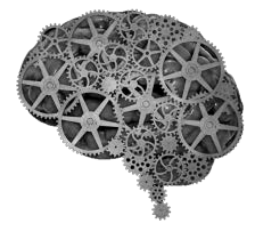

COMPANY GROUP "INTELLEKT"

\author{
Охрименко И.В. \\ МВД России \\ Москва, Россия
}

doi: 10.18411//j2016-9-3-09

idsp 000001: lj2016-18-3-09

\section{К вопросу о зависимости теневой экономики от уровня образования населения (на примере Турции)}

Теневая экономика представляет собой систему экономических взаимоотношений хозяйствующих субъектов, возникающих в процессе осуществления ими экономической деятельности, напрямую не запрещенной законодательством, но сам характер осуществления которой ведется с нарушением действующих норм в сфере налогового, трудового права и др., а также запрещенную законодательством деятельность в целях извлечения прибыли. Например, по различным источникам, размер теневой экономики в Турции представляет собой величину от 30 до 60\% ВВП страны.

Прямая связь между неофициальной занятостью населения и низким уровнем образования отмечается в работах Н. Юзбашиоглу, Т. Гюльоглу, А.Коркмаз и М. Кип. Сотрудники низкой квалификации, не востребованные в официальном секторе экономики, ищут возможность работы, невзирая на статус предлагающего ее предприятия. Именно по этой причине в теневом секторе трудятся работники низкой квалификации.

Тот факт, что низкое качество системы образования Турции, недостаточный охват им населения и запаздывание в преподавании в учебных заведениях знаний, формирующих востребованные профессиональные компетенции, является одной из главных проблем Турции, отмечает большинство турецких авторов, занимающихся вопросами выявления источников роста теневого сектора. В их числе, помимо ранее упомянутых, М. Башесгиоглу, С. Ульген и У. Озтюрк. 
Турецкие исследователи указывают, что образовательная политика Турции не отвечает требованиям обеспечения рынка труда высококвалифицированной рабочей силой. Основными при этом называют следующие причины:

- во-первых, программы подготовки специалистов в учебных заведениях не ориентированы на потребности экономики и не готовят выпускников по востребованным специальностям;

- во-вторых, не работает система профессиональной переподготовки кадров для вновь возникающих направлений и условий производственной деятельности.

В качестве заключения целесообразно привести ряд выводов. Итак, для современной Турции характерно следующее.

1) Невозможность повышения квалификации за счет реализации государственных программ не оставляет турецким работникам возможности получить официальную работу и толкает их в теневой сектор.

2) Тот факт, что низкое качество системы образования Турции, недостаточный охват им населения и запаздывание в преподавании в учебных заведениях знаний, формирующих востребованные профессиональные компетенции, является одной из главных проблем Турции, отмечает большинство турецких авторов, занимающихся вопросами выявления источников роста теневого сектора.

3) Высокий уровень образованности населения обеспечит стабильность и рост экономического развития страны. В свою очередь, высокий показатель ВВП на душу населения позволяет гражданам расходовать все более значительные средства на повышение своего образования, а рост официального сектора экономики повысит налоговые отчисления, которые могут быть направлены на повышение уровня образования населения.

4) Государственные образовательные программы увеличат эффективность использования человеческих ресурсов, то есть стоимость национального человеческого капитала. Такое положение вещей будет прямым проявлением взаимовыгодного сотрудничества граждан и государства, что означает пост уровня национальной экономической безопасности.

5) Образованность дает понимание налоговой политики, как основы реализации социальных, в том числе образовательных программ. Это 
увеличивает собираемость налогов, что повышает социальную защищенность граждан, социальная защищенность граждан обеспечивает им осознание выполнения государством Общественного договора, как основы национальной стабильности и экономической безопасности. Это, в свою очередь, является основой для соблюдения принципов налоговой морали.

\section{Литература:}

1. Заславская Т.И. Проблема распространения и институционализации неправовых социальных практик. Российская экономика на новых путях. / Под ред. Э.И. Гойзмана и Р.Н. Евстигнеева. М.: Институт Бизнеса и Экономики, 2003.

2. Звягин А.А. Факторы роста коррупции и теневой экономики., взаимосвязь коррупции и теневой экономики./Материалы Всероссийской научной конференции. Москва, 6 июня 2007 г. - М.: 2007.

3. Латов Ю.В. Неформальная экономика как глобально-историческое явление // Теневая экономика: экономический и социальный аспекты. - М.: ЮНИОН, 1999.

4. Yüzbaşığlu, N. (2010) Kayıt Dışı Ekonomi ve İstihdam Üzerindeki Etkileri. Ankara: Türkiye Kamu-Sen Yayınları, No. 32.

5. Güloğlu, T., Korkmaz, A., Kip, M. (2003) Türkiye'de Kayıtdışı İstihdam Gerçeğine Bir Bakış” Sosyal Siyaset Konferansları Dergisi, 45(1).

6. Başesgioğlu, M. (2007) "İstihdamın Önemi, Kayıt Dışı İstihdamın ve İşsizliğin Azaltılmas1" Mercek,12 (46).

7. Ülgen, S., Öztürk, U. (2007) Kayıtdışı Ekonomi Türkiye Serüveni. Deloitte CEO Serisi. 